\title{
PENGARUH SISTEM OLAH TANAH TERHADAP POPULASI DAN BIOMASSA CACING TANAH PADA LAHAN BEKAS ALANG-ALANG (Imperata cylindrica L.) YANG DITANAMI KEDELAI (Glycine max L.) MUSIM KEDUA
}

\author{
Firmanda Aliesa Sembiring, Sri Yusnaini, Henrie Buchari \& Ainin Niswati \\ Jurusan Agroteknologi, Fakultas Pertanian Universitas Lampung \\ Jl. Prof. Dr. Soemantri Brodjonegoro No. 1 Bandar Lampung 35145 \\ E-mail : firmanda_pelawi@yahoo.com
}

\begin{abstract}
ABSTRAK
Ekstensifikasi pertanian merupakan salah satu cara untuk meningkatkan produksi tanaman pangan, salah satunya dengan pemanfaatan lahan bekas alang-alang bagi pertanaman kedelai. Meskipun lahan yang ditumbuhi alang-alang memiliki sifat tanah yang buruk, namun jika lahan alang-alang diberakan lebih dari 10 tahun dan pengolahan tanah dilakukan secara tepat diduga kandungan bahan organik yang ada telah cukup untuk mendukung perbaikan sifat fisik, kimia dan biologi tanah. Penelitian ini bertujuan untuk mempelajari pengaruh sistem olah tanah terhadap populasi dan biomassa cacing tanah pada lahan bekas alang-alang (Imperata cylindrica L.) yang ditanami kedelai (Glycine max L.) musim kedua. Penelitian ini dilakukan dengan menggunakan rancangan acak kelompok (RAK) dengan 6 ulangan. Perlakuan yang diterapkan adalah Olah Tanah Intensif (OTI), Olah Tanah Minimum (OTM) dan Tanpa Olah Tanah (TOT). Data yang diperoleh diuji homogenitas ragamnya dengan uji Bartlett dan diuji aditifitasnya dengan uji Tukey, kemudian dianalisis sidik ragamnya dengan uji Beda Nyata Terkecil (BNT) pada taraf 5\%. Selanjutnya dilakukan uji korelasi antara variabel utama (populasi dan biomassa cacing tanah) dengan variabel pendukung ( $\mathrm{pH}, \mathrm{C}$-organik, $\mathrm{N}$-total, suhu, kelembaban dan ruang pori total tanah). Hasil penelitian menunjukkan bahwa, populasi dan biomassa cacing tanah pada perlakuan TOT dan OTM lebih tinggi daripada OTI pada periode pengamatan 1 HST, 48 HST dan 95 HST. Penyebaran populasi dan biomassa cacing tanah pada kedalaman 0-10 cm lebih banyak daripada kedalaman 10-20 cm maupun 20-30 cm pada setiap perlakuan sistem olah tanah. Dari hasil identifikasi ditemukan 2 genus cacing tanah, yaitu Pontoscolex sp. dan Pheretima sp. Populasi dan biomassa cacing tanah tidak berkorelasi dengan pH, Corganik, N-total, kelembaban dan suhu tanah tetapi berkorelasi nyata dengan ruang pori total tanah.
\end{abstract}

Kata Kunci : Alang-alang (Imperata cylindrica L.), cacing tanah, sistem olah tanah.

\section{PENDAHULUAN}

Ekstensifikasi pertanian merupakan salah satu cara untuk meningkatkan produksi tanaman pangan. Usaha ekstensifikasi dilakukan dengan cara pembukaan lahan baru bagi pertanian, salah satunya dengan pemanfaatan lahan bekas alang-alang bagi pertanaman kedelai. Lahan alang-alang merupakan lahan tidak produktif yang tersebar cukup luas di Indonesia. Menurut Marufah (2008), luas lahan alang-alang di Indonesia mencapai 8,5 juta ha atau sekitar $4,47 \%$ dari luas wilayah Indonesia. Di Lampung luas lahan alang-alang sekitar 75.921 ha, artinya jika lahan tersebut dapat dimanfaatkan dengan baik tentunya peningkatan produksi pertanian akan lebih optimal (Anny, 2005).

Permasalahan utama pemanfaatan lahan yang ditumbuhi alang-alang untuk pertanian adalah buruknya sifat fisik, kimia dan biologi tanah (Marufah, 2008). Meskipun lahan yang ditumbuhi alang-alang memiliki sifat fisik, kimia dan biologi tanah yang buruk, namun jika lahan alang-alang tersebut diberakan lebih dari 10 tahun diduga kandungan bahan organik yang ada telah cukup untuk mendukung perbaikan sifat fisik, kimia dan biologi tanah pada lahan tersebut. Untuk itu, diperlukan suatu sistem pengolahan tanah yang tepat, sehingga lahan bekas alang-alang dapat menjadi produktif dan mampu menunjang peningkatan produksi pertanian. Salah satu parameter sifat biologi tanah yang dapat digunakan untuk mengetahui bahwa lahan tersebut telah dapat digunakan sebagai lahan pertanian adalah dengan mengetahui keberadaan cacing tanah pada lahan tersebut. Cacing tanah merupakan salah satu biota tanah yang memiliki peranan penting sebagai indikator kesuburan tanah. Pola penggunaan lahan yang intensif 
mempunyai pengaruh terhadap populasi, biomassa, dan keanekaragaman cacing tanah. Sebaliknya cacing tanah mempunyai peranan penting terhadap perbaikan sifat tanah seperti menghancurkan bahan organik dan mencampuradukkannya dengan tanah, sehingga terbentuk agregat tanah dan memperbaiki struktur tanah (Buck, Langmaack dan Schrader, 1999).

Tindakan budidaya pertanian pada lahan bekas alang-alang berupa sistem olah tanah dapat memengaruhi kehidupan cacing tanah. Penelitian ini bertujuan untuk mempelajari pengaruh sistem olah tanah terhadap populasi dan biomassa cacing tanah pada lahan bekas alang-alang (Imperata cylindrica L.) yang ditanami kedelai (Glycine max L.) musim kedua.

\section{BAHAN DAN METODE}

Penelitian ini dilaksanakan bulan Agustus November 2012 pada lahan bekas alang-alang di Desa Blora Indah Kelurahan Kelurahan Segalamider Kecamatan Tanjung Karang Barat Kota Bandar Lampung. Perhitungan populasi cacing tanah dilakukan di lapang sedangkan biomassa, identifikasi cacing tanah, dan analisis contoh tanah dilakukan di Laboratorium Ilmu Tanah, Fakultas Pertanian, Universitas Lampung.

Penelitian ini dilakukan dengan menggunakan rancangan acak kelompok (RAK) dengan 6 ulangan. Perlakuan yang diterapkan adalah TOT $=$ Tanpa Olah Tanah, OTM = Olah Tanah Minimum, OTI = Olah Tanah Intensif. Semua perlakuan diaplikasikan pupuk dasar dengan dosis $\mathrm{N}=50 \mathrm{~kg} \mathrm{ha}^{-1}, \mathrm{P}_{2} \mathrm{O}_{5}=200 \mathrm{~kg} \mathrm{ha}^{-1}$ dan $\mathrm{K}_{2} \mathrm{O}=100 \mathrm{~kg} \mathrm{ha}^{-1}$. Sebagai indikator kesuburan tanah pada lahan bekas alang-alang yang akan dijadikan lahan pertanian, maka lahan tersebut ditanami tanaman kedelai varietas Anjasmoro secara tugal dengan jarak $25 \mathrm{~cm} \mathrm{x}$ $25 \mathrm{~cm}$.

Data yang diperoleh diuji homogenitas ragamnya dengan uji Bartlett dan diuji aditifitasnya dengan uji Tukey, kemudian dianalisis sidik ragamnya dengan uji Beda Nyata Terkecil (BNT) pada taraf $5 \%$. Selanjutnya dilakukan uji korelasi antara variabel utama (populasi dan biomassa cacing tanah) dengan variabel pendukung ( $\mathrm{pH}, \mathrm{C}$-organik, N-total, suhu, kelembaban dan ruang pori total tanah).

\section{HASIL DAN PEMBAHASAN}

Dari ringkasan signifikansi analisis ragam (Tabel 1) menunjukkan bahwa perlakuan sistem olah tanah berpengaruh nyata terhadap populasi dan biomassa cacing tanah pada pengambilan periode pengamatan satu hari setelah pengolahan tanah (1 HST), setelah tanaman kedelai berusia 49 hari (49 HST) serta 95 hari (95 HST).

Hal ini dikarenakan lahan yang sedang digunakan untuk penelitian merupakan lahan musim tanam kedua sehingga diduga penerapan sistem olah tanah setelah pemberaan lebih dari 10 tahun pada musim tanam pertama menyebabkan terjadinya perubahan sifat tanah yang mendukung kehidupan cacing tanah di dalam tanah pada musim tanam kedua. Menurut Rachman dkk. (2003), setiap upaya pengolahan tanah akan menyebabkan terjadinya perubahan sifat-sifat tanah. Perubahan sistem olah tanah menjadi olah tanah konservasi dan ditambah pemanfaatkan sisa gulma sebagai mulsa organik di lahan pertanaman diharapkan dapat memperbaiki sifat fisik, kimia dan biologi tanah yang selanjutnya dapat meningkatkan produksi tanaman. Kegiatan ini diharapkan juga dapat meningkatkan populasi dan biomassa cacing tanah yang dapat dijadikan indikator kesuburan tanah (Ansyori, 2004).

Dari Gambar 1 tampak bahwa populasi dan biomassa cacing tanah yang terkoleksi selama tiga periode waktu pengamatan dari periode satu hari setelah pengolahan tanah (1 HST), setelah tanaman kedelai berusia 48 hari (48 HST) serta 95 hari (95 HST) menunjukkan peningkatan jumlah populasi dan bobot biomassa cacing tanah yang berbeda pada setiap perlakuan sistem olah tanah. Jumlah populasi dan bobot biomassa cacing tanah yang tertinggi diperoleh pada

Tabel 1. Ringkasan signifikansi analisis ragam pengaruh sistem olah tanah terhadap populasi dan biomassa cacing tanah pada tiga periode waktu pengamatan.

\begin{tabular}{ccc}
\hline \multirow{2}{*}{ Periode waktu penga matan } & \multicolumn{2}{c}{ S ignifikansi } \\
\cline { 2 - 3 } & Populasi Cacing Tanah & Bi omassa Cacing Tanah \\
\hline Satu hari setelah pengolahan tanah & $* *$ & $* *$ \\
Set elah tanaman kedelai berusia 48 hari & $* *$ & $* *$ \\
Set elah tanaman kedelai berusia 95 hari & $* *$ & $* *$ \\
\hline
\end{tabular}

Keterangan : $* *=$ sangat berbeda nyata pada taraf $1 \%$. 

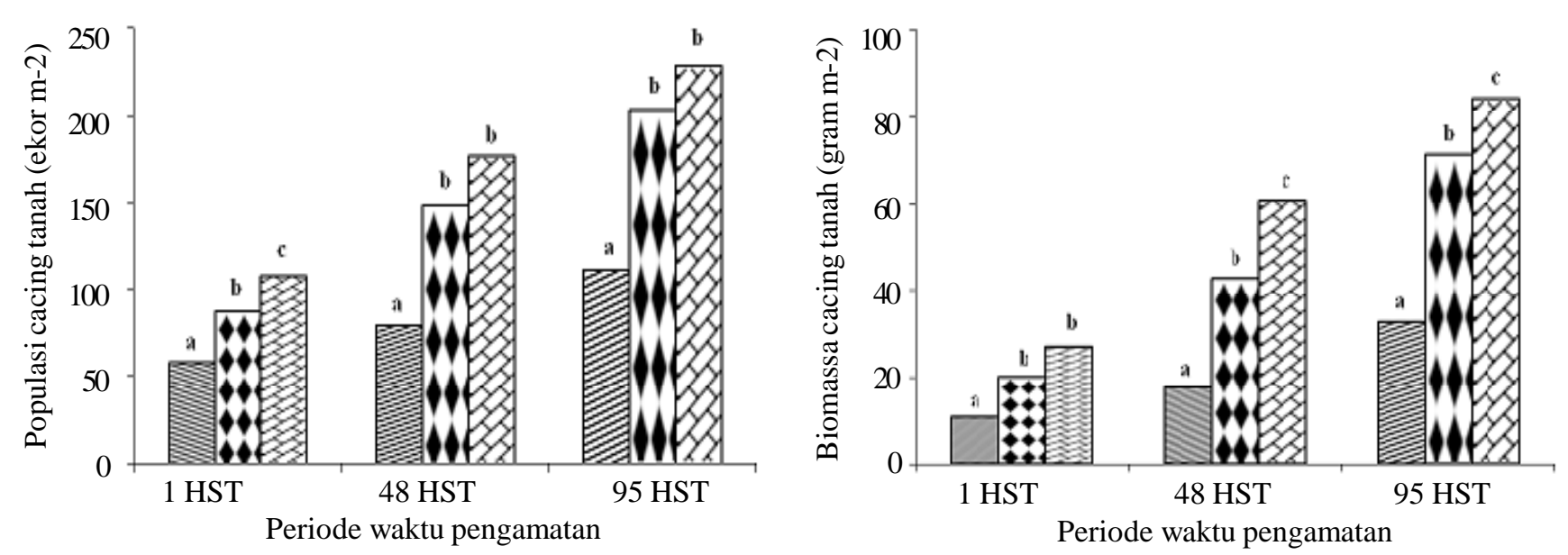

Gambar 1. Populasi dan biomassa cacing tanah pada beberapa perlakuan sistem olah tanah dalam tiga periode waktu pengamatan. Huruf di atas bar merupakan notasi BNT pada taraf nyata 5\%, OTI ( Tanah Intensif; OTM $(\mathbf{D})=$ Olah Tanah Minimum; TOT $(\bar{Z})=$ Tanpa Olah Tanah, 1 HST = satu hari setelah pengolahan tanah; $48 \mathrm{HST}=$ setelah tanaman kedelai berusia 48 hari; $95 \mathrm{HST}=$ setelah tanaman kedelai berusia 95 hari.
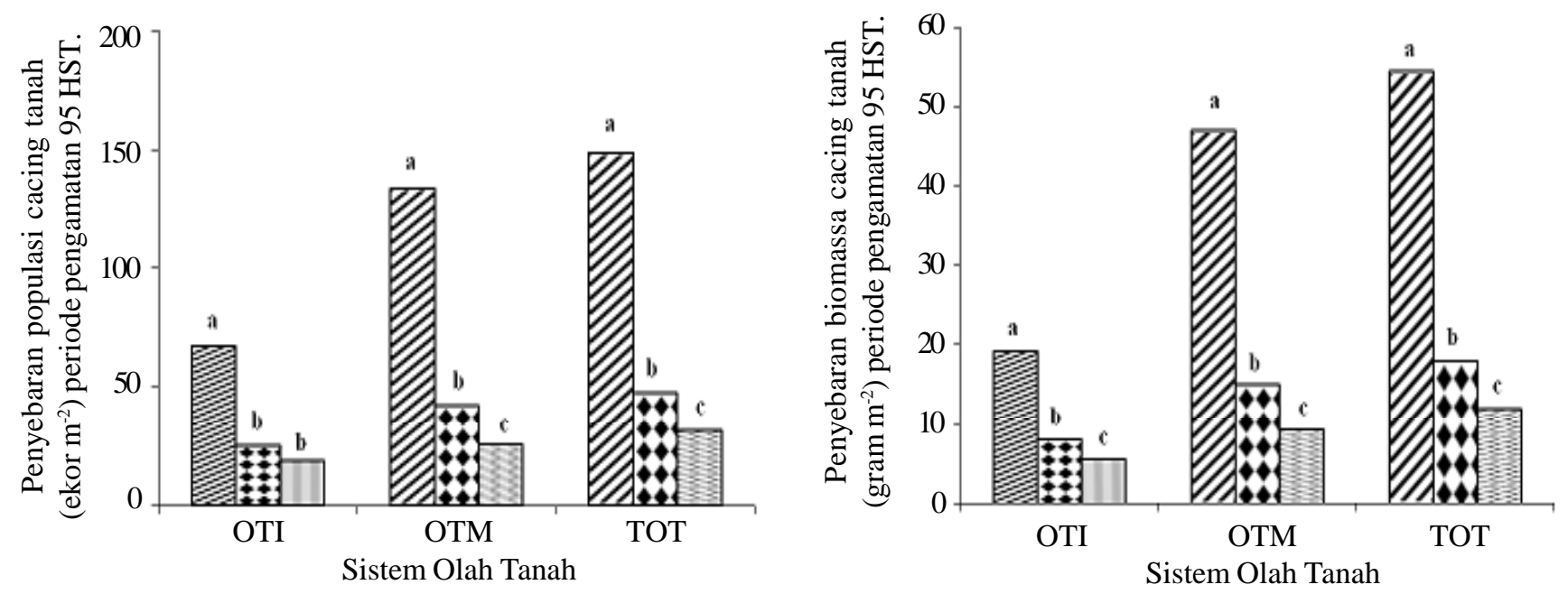

Gambar 2. Penyebaran populasi dan biomassa cacing tanah pada beberapa perlakuan sistem olah tanah dalam kedelaman tanah yang berbeda. Huruf di atas bar merupakan notasi BNT pada taraf nyata 5\%, OTI ( $)$ = Olah Tanah Intensif; OTM ( HST $=$ periode pengamatan setelah tanaman kedelai berusia 95 hari.

periode pengamatan setelah tanaman kedelai berusia 95 hari (95 HST). Populasi cacing tanah pada TOT tidak berbeda nyata dengan OTM tetapi berbeda nyata dengan OTI, sedangkan biomassa cacing tanah pada TOT berbeda nyata dengan OTM dan OTI. Pada TOT rata-rata jumlah populasi cacing tanah tertinggi sebanyak 228,67 ekor $\mathrm{m}^{-2}$ serta bobot biomassa tertinggi seberat $84,37 \mathrm{~g} \mathrm{~m}^{-2}$, dan pada OTM rata-rata jumlah populasi cacing tanah tertinggi sebanyak 202,67 ekor $\mathrm{m}^{-2}$ serta bobot biomassa tertinggi seberat $71,42 \mathrm{~g} \mathrm{~m}^{-2}$, sedangkan pada OTI diperoleh rata-rata jumlah populasi cacing

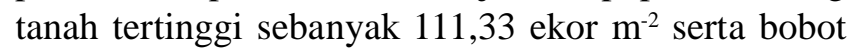
biomassa tertinggi seberat $32,79 \mathrm{~g} \mathrm{~m}^{-2}$. Hal ini sejalan dengan penelitian Brown dkk. (2002) yang menyimpulkan bahwa populasi cacing tanah TOT $5 \mathrm{kali}$ lebih tinggi dibandingkan OTI, serta penelitian Ansyori (2004) menunjukkan bahwa TOT dan OTM cenderung 
memiliki biomassa cacing tanah yang lebih tinggi dibandingkan dengan OTI pada permukaan tanah.

Dari Gambar 2 tampak bahwa penyebaran populasi dan biomassa cacing tanah yang terkoleksi menunjukkan suatu penurunan jumlah populasi dan bobot biomassa cacing tanah seiring bertambahnya kedalaman tanah pada setiap perlakuan sistem olah tanah. Pada periode pengamatan setelah tanaman kedelai berusia 95 hari (95 HST), penyebaran populasi dan biomassa cacing tanah pada kedalaman $0-10 \mathrm{~cm}$ memiliki jumlah populasi dan bobot biomassa cacing tanah yang lebih tinggi dibandingkan pada kedalaman 10-20 cm dan 20$30 \mathrm{~cm}$, kecuali penyebaran populasi cacing tanah pada OTI, penyebaran populasi cacing tanah pada kedalaman $10-20 \mathrm{~cm}$ tidak berbeda nyata dengan kedalaman 20-30 $\mathrm{cm}$. Hal ini diduga karena perilaku dan kebiasaan kelompok cacing tanah pada lahan tersebut merupakan cacing tanah pemakan seresah tanaman di permukaan tanah yakni kelompok cacing tanah epigaesis.

Menurut Edwards (1998); Paoletti (1999); dan Hanafiah dkk. (2005), cacing tanah secara umum dapat dikelompokkan berdasarkan tempat hidup, kotoran, kenampakan warna, dan makanan kesukaannya. Kelompok cacing tanah epigaesis merupakan kelompok cacing tanah yang aktif di permukaan tanah pada kedalaman tanah kurang dari $8 \mathrm{~cm}$, warna gelap, penyamaran efektif, tidak membuat lubang, kotoran tidak tampak jelas, pemakan seresah di permukaan tanah dan tidak mencerna tanah.

Hasil uji korelasi (Tabel 2) menujukkan bahwa populasi dan biomassa cacing tanah tidak berkorelasi dengan $\mathrm{pH}, \mathrm{C}$-organik, $\mathrm{N}$-total, suhu dan kelembaban tanah tetapi berkorelasi nyata dengan ruang pori total tanah. Hal ini dikarenakan singkatnya waktu penelitian dan tingginya nisbah $\mathrm{C} / \mathrm{N}$ rasio mulsa alang-alang $(\mathrm{C} / \mathrm{N}$
100), sehingga diduga mulsa alang-alang belum terdekomposisi secara sempurna dan belum berpengaruh terhadap $\mathrm{pH}$,

C-organik, N-total, suhu dan kelembaban tanah. Sedangkan ruang pori total tanah erat hubungannya dengan aerasi tanah. Berdasarkan hasil analisis ruang pori total tanah, lahan bekas alang-alang memiliki kelas ruang pori total baik dengan persentase ruang pori total $54,74-60,58 \%$, sehingga diduga memiliki aerasi tanah yang baik untuk mendukung proses respirasi dan akivitas cacing tanah pada lahan tersebut. Hal ini sejalan dengan pernyataan Utomo (1995); Franzeluebers dkk. (1995) dalam Buchari (2002), yang menerangkan bahwa pengaruh perlakuan sistem olah tanah terhadap beberapa sifat tanah seperti C-mik, C-organik dan N-total tanah baru terlihat setelah beberapa tahun. Makalew (2001), melaporkan bahwa setelah 16 tahun, penerapan OTM meningkatkan C-organik pada permukaan $5 \mathrm{~cm}$ pada lahan yang diolah.

Pengidentifikasian cacing tanah dapat dilakukan apabila cacing tanah yang didapatkan berumur cukup dewasa sehingga segmentasi dan letak klitellum sudah tampak jelas sesuai dengan metode identifikasi menggunakan kunci determinasi cacing tanah modifikasi Hanafiah (Hanafiah dkk., 2005). Hasil pengamatan identifikasi cacing tanah yang didapatkan pada lokasi penelitian terdapat 2 genus dari 2 famili yang berbeda, yaitu genus Pontoscolex sp. (famili Glossoscolecidae) dan genus Pheretima sp. (famili Megascolecidae). Hal ini diduga karena pengaruh penggunaan bahan kimia dalam aktivitas budidaya pertanian pada sistem penggunaan lahan modern yang menggunakan pupuk kimia untuk mencukupi kebutuhan unsur hara tanaman, menggunakan herbisida untuk mengendalikan gulma, dan menggunakan pestisida dan fungisida untuk

Tabel 2. Korelasi antara populasi dan biomassa cacing tanah dengan $\mathrm{pH}, \mathrm{C}$-organik, $\mathrm{N}$-total, suhu, kelembaban dan ruang pori total tanah pada periode setelah tanaman kedelai berusia 95 hari (95 HST).

\begin{tabular}{lcc}
\hline Variabel & \multicolumn{2}{c}{ Koefisien korelasi (r) } \\
\cline { 2 - 3 } & Popula si cacing tanah & Biomassa cacing tanah \\
\hline pH & $-0,38^{\text {tn }}$ & $-0,39^{\text {tn }}$ \\
C-Organik & $-0,36^{\text {tn }}$ & $-0,36^{\text {tn }}$ \\
N-Total & $0,13^{\text {tn }}$ & $0,09^{\text {tn }}$ \\
Suhu & $-0,31^{\text {tn }}$ & $-0,31^{\text {tn }}$ \\
Kelembaban & $0,49^{\text {tn }}$ & $0,49^{\text {n }}$ \\
${ }^{*}$ Ruang Pori Total & $-0,88^{*}$ & $-0,89^{*}$ \\
\hline
\end{tabular}

Keterangan $:$ tn $=$ tidak berbeda nyata pada taraf nyata $5 \%$ dan $1 \% ; *$ = berbeda nyata pada taraf nyata $5 \%$, *)ruang pori total tanah disadur dari data penelitian Destra (2014). 
mengendalikan hama dan penyakit tanaman, sehingga bahan kimia yang digunakan akan berpengaruh terhadap kondisi tanah dan kehidupan biota tanah, termasuk jenis cacing tanah. Hal ini sejalan dengan penelitian Yusnaini dkk. (2008) tentang perubahan populasi cacing tanah pada berbagai sistem penggunaan lahan pada daerah Sumber Jaya, Lampung Barat, yang melaporkan bahwa terdapat 2 jenis cacing tanah yang ditemukan, yaitu Pheretima sp. dan Pontoscolex sp.

Berdasarkan kriteria identifikasi Hanafiah dkk. (2005), cacing tanah genus Pontoscolex sp. (famili Glossoscolecidae) merupakan cacing tanah yang letak klitelum berada pada segmen 14-20 (Gambar 3.a) serta memiliki setae yang tersusun menurut pola lumbrisin (berpasangan erat) (Gambar 3.b). Berdasarkan kriteria identifikasi Hanafiah dkk. (2005), cacing tanah dengan genus Pheretima sp. (famili Megascolecidae) merupakan cacing tanah yang letak klitelum berada di depan segmen ke-15 (Gambar 3.c) serta memiliki setae yang tersusun menurut pola perisetin (Gambar 3.d).

Pada TOT teridentifikasi 96 ekor $\mathrm{m}^{-2}$ Pontoscolex sp. dan 32 ekor $\mathrm{m}^{-2}$ Pheretima sp. yang ditemukan pada kedalaman 0-10 cm, dan pada OTM teridentifikasi 48 ekor $\mathrm{m}^{-2}$ Pontoscolex sp. dan 32 ekor $\mathrm{m}^{-2}$ Pheretima $\mathrm{sp}$. yang ditemukan pada kedalaman 0-

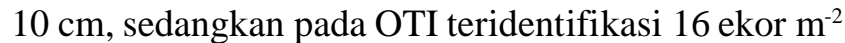
Pontoscolex sp. yang ditemukan pada kedalaman 20-
$30 \mathrm{~cm}$ (Tabel 3). Pada Tabel 3 tampak bahwa pada OTI tidak dijumpai genus cacing tanah Pheretima sp. Hal ini diduga karena terganggunya tanah secara intensif serta tidak adanya mulsa organik yang berasal dari sisasisa gulma di permukaan tanah, berpengaruh terhadap kondisi lingkungan tanah dan menyebabkan terjadinya suatu gangguan terhadap cacing tanah, sehingga meningkatkan proses penguapan tanah sebagai dampak perubahan kondisi suhu dan kelembaban tanah yang mempengaruhi keberadaan genus cacing tanah Pheretima sp. pada perlakuan tersebut.

Genus cacing tanah Pontoscolex sp. memilik kemampuan adaptasi yang lebih baik terhadap perubahan kondisi lingkungan tanah dibandingkan genus cacing tanah Pheretima sp. Genus cacing tanah Pontoscolex sp. termasuk genus cacing tanah eksotik dan tersebar luas di banyak lahan terganggu di seluruh dunia (Edwards, 1998). Sugiarto, Handayanto dan Agustina (2002) menyatakan bahwa perbedaan penggunaan lahan akan mempengaruhi populasi dan komposisi makrofauna tanah. Hal ini sejalan dengan penelitian Chan (2001), yang menunjukkan bahwa berkurangnya populasi cacing tanah sering ditemukan pada pengolahan tanah intensif karena adanya perubahan lingkungan tanah yang tidak diinginkan sebagai dampak pengolahan tanah yang berlebihan.
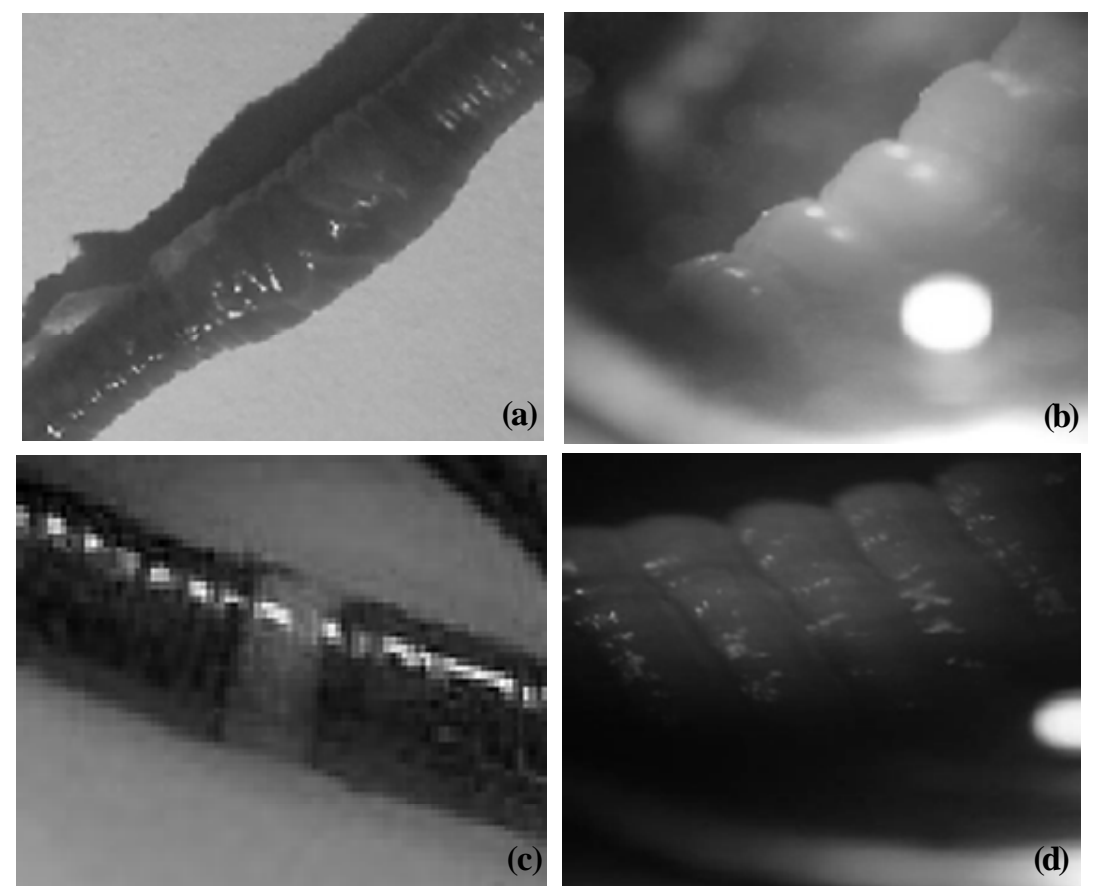

Gambar 3. (a) Klitelum Pontoscolex sp., (b) Setae lumbrisin, (c) Klitelum Pheretima sp., (d) Setae perisetin. 
Tabel 3. Genus cacing tanah yang teridentifikasi pada periode pengamatan setelah tanaman kedelai berusia 95 hari (95 HST).

\begin{tabular}{lccc}
\hline Genus cacing tanah & \multicolumn{3}{c}{ Jumlah cacing tanah $\left(\mathrm{ek}\right.$ or $\left.\mathrm{m}^{-2}\right)$} \\
\cline { 2 - 4 } & OTI & OTM & TOT \\
\hline Pontoscolex $\mathrm{sp}$. & $16^{*}$ & $48^{* *}$ & $96^{* *}$ \\
Pheretima $\mathrm{sp}$. & - & $32^{* *}$ & $32^{* *}$ \\
\hline
\end{tabular}

Keterangan : OTI $=$ Olah Tanah Intensif; OTM = Olah Tanah Minimum; TOT = Tanpa Olah Tanah, * = ditemukan pada kedalaman tanah $20-0 \mathrm{~cm} ; * *=$ ditemukan pada kedalaman tanah $0-10 \mathrm{~cm}$.

\section{KESIMPULAN}

Dari penelitian dapat disimpulkan bahwa populasi dan biomassa cacing tanah pada perlakuan TOT dan OTM lebih tinggi daripada OTI pada periode pengamatan satu hari setelah pengolahan tanah (1 HST), setelah tanaman kedelai berusia 48 hari (48 HST) serta 95 hari (95 HST). Penyebaran populasi dan biomassa cacing tanah pada kedalaman $0-10 \mathrm{~cm}$ lebih banyak daripada kedalaman $10-20 \mathrm{~cm}$ maupun 20-30 cm pada setiap perlakuan sistem olah tanah. Terdapat 2 genus cacing tanah yang didapat dari hasil identifikasi, yaitu Pontoscolex sp. dan Pheretima sp. Populasi dan biomassa cacing tanah tidak berkorelasi dengan $\mathrm{pH}, \mathrm{C}$-organik, N-total, suhu dan kelembaban tanah tetapi berkorelasi nyata dengan ruang pori total tanah.

\section{DAFTAR PUSTAKA}

Anny. 2005. Teknologi untuk Menyulap Lahan Alang-Alang Menjadi Lahan Pertanian. Pusat Penelitian dan Pengembangan Tanaman dan Agroklimat. Bogor.

Ansyori. 2004. Potensi Cacing Tanah sebagai Alternatif Bio-Indikator Pertanian Berkelanjutan. Institut Pertanian Bogor. Bogor. Makalah Pribadi Falsafah Sains (PPS 702).

Buchari, H. 2002. Kajian Lumbung Karbon dan Nitrogen Labil Pada Lahan Alang-Alang (Imperata cylindria) di Tanah Ultisol. Institut Pertanian Bogor. Bogor. 47 hlm.

Buck, C., M. Langmaack and S. Schrader. 1999. Nutrient Content of Earthworm Cast Influenced by Different Mulch Types. Eur. Soil. Bio. J. 55: 23-30.

Brown, G.G., N.P. Benito, A. Pasini., K.D. Sautter, M.F. Guimaraes dan E. Tores. 2002. No-Tillage Greatly Increases Earthworm Population in Parana State, Brazil. $7^{\text {th }}$ International Symposium on Earthworm Ecology. Cardiff. Wales.

Chan, K.Y. 2001. An Overview of Some Tillage Impact on Earthworm Population Abudance and Diversity-Implications for Functioning in Soils. Soil and Tillage Res. J. 57: 547-554.

Destra, H. 2014. Pengaruh Sistem Olah Tanah Terhadap Infiltrasi Tanah Pada Lahan Bekas Alang-Alang (Imperata cylindrica L.) yang Ditanami Kedelai (Glycine max L.) Musim Kedua. Skripsi. Universitas Lampung. Bandar Lampung. $67 \mathrm{hlm}$.

Edwards, C.A. 1998. Earthworm Ecology. St. Lucie Press. Washington, DC. $389 \mathrm{hlm}$.

Hanafiah, K.A., I. Anas, A. Napoleon dan N. Goffar. 2005. Biologi Tanah: Ekologi dan Makrobiologi Tanah. Rajawali Press. Jakarta. $166 \mathrm{hlm}$.

Makelew, D.N. 2001. Keanekaragaman Biota Tanah Pada Agroekosistem Tanpa Olah Tanah (TOT). Program Pascasarjana Institut Pertanian Bogor. Bogor. Makalah Falsafah Sains.

Marufah, D. 2008. Pengelolaan Gulma Alang-Alang Pada Lahan Perkebunan. http:// marufah.blog.uns.ac.id. Diakses pada tanggal : 25 September 2012.

Paoletti, M.G. 1999. The Role of Earthworms for Assessment of Sustainability and as Bioindicators. Agri. Eco. Env. J. 74: 137- 155. 
Rachman, A., S.H. Anderson, C.J. Gantzer, and A.L. Thompson. 2003. Influence of Long Term Cropping System on Soil Physical Properties Related to Soil Erodibility. Soil Sci. Soc. Am. J. 67: 637-644.

Sugiarto, Y., E. Handayanto dan L. Agustina. 2002. Pengaruh Sistem Penggunaan Lahan Hutan terhadap Diversitas Makroinvertebrata Tanah di RPH Jatirejo. Kediri. Jawa Timur. BioSmart. 4(2): 66-69.
Yusnaini, S., A. Niswati, M.A.S. Arif and M. Nonaka. 2008. The Changes of Earthworm Population and Chemical Properties of Tropical Soils under Different Land Use Systems. J. Tanah Trop. 13: 131-137. 